\title{
COCHLEAR INVOLVEMENT IN VITILIGO PATIENTS
}

Contributions: A Study design/planning B Data collection/entry C Data analysis/statistics C Data analysis/statistics D Data interpretation E Preparation of manuscrip F Literature analysis/search $\mathrm{G}$ Funds collection

\section{Abeir Osman Dabbous $s^{1, A, C-F}$, Mariam Magdy Medhat ${ }^{1, A-B, F}$, Marwa Salah El-Din El-Mesidy 2,A-B,D}

\author{
${ }^{1}$ Audio-Vestibular Unit, Otorhinolaryngology Department, Kasr Al-Ainy \\ Faculty of Medicine, Cairo University, Egypt \\ ${ }^{2}$ Department of Dermatology, Kasr-Al-Ainy Faculty of Medicine, Cairo University, Egypt \\ Corresponding author: Abeir Osman Dabbous; Audio-Vestibular Unit, \\ Otorhinolaryngology Department, Kasr Al-Ainy Faculty of Medicine, Cairo University, \\ Cairo, Egypt; email: abeirdabbous@kasralainy.edu.eg; Phone: +201146686466
}

\begin{abstract}
Background: Vitiligo is a common chronic disease of pigmentation, which may be accompanied by audiological abnormalities.

Material and methods: The aim of this study was to assess vitiligo patients in terms of hearing thresholds using conventional pure tone audiometry $(0.25$ to $8 \mathrm{kHz})$, high frequency pure tone audiometry (10 and $12.5 \mathrm{kHz})$, as well as Transient Evoked Otoacoustic Emissions (TEOAEs). We correlated the audiometric findings with vitiligo duration and severity. The study included 75 subjects with a mean age of $29.7 \pm 8.6$ years. There were 50 vitiligo patients and 25 age and gender matched healthy controls who had never had any audiological condition or exposed to excessive noise.

Results: Only $24 \%$ of vitiligo patients had high frequency sensorineural hearing loss (SNHL) using conventional audiometry and the majority (76\%) had bilaterally normal hearing. The majority (90\%) of vitiligo patients had SNHL in extended high frequency audiometry. There was a statistically significant difference between the cases and controls regarding TEOAE SNR at $5 \mathrm{kHz}$, and nearly half of the normal hearers had an abnormal TEOAE. Vitiligo patients were found to have subclinical inner ear dysfunction compared with the controls. There was a statistically significant correlation between PTA and age of the patients but not with vitiligo duration or severity.

Conclusions: The audiometric findings of the vitiligo group and the statistically significant differences from the control group suggest a subclinical involvement of the cochlea, probably related to the vitiligo condition, but not affected by vitiligo duration or severity. We therefore recommend the use of extended high frequency audiometry and otoacoustic emission tests for early detection of inner ear involvement in vitiligo.
\end{abstract}

Key words: vitiligo $\bullet$ cochlea $\bullet$ high frequency $\bullet$ sensorineural hearing loss $\bullet$ audiometry, otoacoustic emission

\section{ZABURZENIA ŚLIMAKOWE U PACJENTÓW Z BIELACTWEM}

\section{Streszczenie}

Wstęp: Bielactwo jest powszechną przewlekłą chorobą powodującą zmiany pigmentacji skóry. W przebiegu tego schorzenia mogą występować zaburzenia słuchu.

Materiał i metody: Celem niniejszego badania było przeprowadzenie oceny słuchu pacjentów z bielactwem nabytym pod kątem progów słyszenia przy użyciu standardowej audiometrii tonalnej ( 0,25 do $8 \mathrm{kHz})$, audiometrii tonalnej wysokich częstotliwości (10 i $12,5 \mathrm{kHz})$, a także badania emisji otoakustycznych wywołanych trzaskiem (TEOAE). Wyniki audiometryczne zostały skorelowane $\mathrm{z}$ czasem trwania i nasileniem bielactwa. W badaniu wzięło udział 75 osób w wieku średnio 29,7 $\pm 8,6$ lat. Grupę badaną stanowiło 50 pacjentów z bielactwem, natomiast grupa kontrolna objęła 25 zdrowych osób dobranych pod względem wieku i płci, u których nigdy nie wystąpiły choroby uszu i które nigdy nie były narażone na nadmierny hałas.

Wyniki: Wyniki standardowej audiometrii tonalnej (PTA) wykazały, że tylko 24\% pacjentów z bielactwem miało ubytek słuchu odbiorczy w obrębie wysokich częstotliwości (SNHL), a u pozostałych 76\% słuch był obustronnie w normie. Z kolei audiometria wysokich częstotliwości wykazała, że większość (90\%) pacjentów z bielactwem miała SNHL. Różnica między pacjentami z bielactwem a grupą kontrolną dla TEOAE dla $5 \mathrm{kHz}$ była istotna statystycznie, a prawie połowa badanych osób zdrowych miała nieprawidłowy wynik TEOAE. U pacjentów z bielactwem w porównaniu z grupą kontrolną stwierdzono utajoną (subkliniczną) dysfunkcję ucha wewnętrznego. Istotna statystycznie korelacja wystąpiła między PTA a wiekiem pacjentów, ale nie między PTA a czasem trwania lub nasileniem bielactwa.

Wnioski: Wyniki audiometrii tonalnej uzyskane w grupie pacjentów z bielactwem i różnice istotne statystycznie w porównaniu z grupą kontrolną sugerują, że zaburzenia ślimakowe u tych osób mają charakter utajony (subkliniczny) i prawdopodobnie są związane ze stanem bielactwa, ale nie z czasem trwania czy nasileniem tej choroby. Dlatego u pacjentów bielactwem zalecamy wykonanie audiometrii wysokich częstotliwości i badania emisji otoakustycznych w celu wczesnego wykrycia wad ucha wewnętrznego.

Słowa kluczowe: bielactwo • ślimak • wysoka częstotliwość • niedosłuch odbiorczy • audiometria • emisje otoakustyczne

\section{Introduction}

Vitiligo is a common chronic disease of pigmentation. Its etiology is unknown, but it is characterized by destruction of melanocytes in the skin that causes hypopigmented and asymptomatic patches with sharply demarcated margins. However, recent clinical and experimental studies suggest there is a systemic destruction of melanocytes, especially in the mucous membranes, eyes, and the membranous labyrinth of the inner ear [1]. The mechanism destroying the 
melanocytes in the skin could also affect the other organs with melanocytes. There are different hypotheses: genetic, autoimmune, auto-cytotoxic, and neural [2].

Melanocytes are also distributed in the membranous labyrinth of the inner ear with the heaviest pigmentation in scala vestibuli. Their role is not fully elucidated, but they are believed to be important for the development of endolymphatic potentials as well as for maintenance and normal function of stria vascularis [2-4]. Despite the fact that the specific functions of otic melanocytes are still unclear, clinical and experimental studies suggest that melanin has semi-conductive properties, responding to acoustic and electrical stimulation. Furthermore, these cells have the ability to convert energy states into molecular rotation and vibration as well as the reverse [5]. Otic melanocytes modulate the function of $\mathrm{Na}^{+} / \mathrm{K}^{+}$-ATPase and potassium channels, which are essential for creating endocochlear potentials [6]. In addition, the melanin is reported to have a protective role against environmental damage [7-10]. Reduced levels and/or activity of pigment cells may result in audiological abnormalities [11-17]. However, most patients with vitiligo are clinically asymptomatic for audiometric abnormalities [18].

Otoacoustic emissions (OAEs) are sounds which arise in the ear canal after the tympanum receives vibrations transmitted backwards through the middle ear from the cochlea. These vibrations occur as a byproduct of a unique and vulnerable cochlear mechanism which has become known as the 'cochlear amplifier' and which contributes greatly to the sensitivity and discrimination of hearing. Transient evoked otoacoustic emissions (TEOAE) are highly sensitive to cochlear pathology in a frequencyspecific way [19].

Normal results in conventional pure tone audiometry (PTA) $(0.25$ to $8 \mathrm{kHz})$ do not exclude cochlear damage. The presence of OAEs is a reliable indicator of structural integrity of the outer hair cells (OHCs) in the cochlea, and their absence might reveal possible subclinical OHC damage corresponding to a particular conventional frequency region (i.e. a cochlear lesion before any evidence occurs in pure tone audiometry). Damage to inner hair cells that code for frequencies above $8 \mathrm{kHz}$ cannot be detected by conventional audiometry, but it is possible with extended high frequency (EHF) audiometry, although this is not routinely used. EHF audiometry may detect impairment in the most basal region of the cochlea [20]. Akay et al. [7]; Anbar et al. [3], Fleissig et al. [2], and Carvalho et al. [21] found an association between vitiligo and different audiological abnormalities.

The rationale behind the current work is to recognise that disturbed auditory function has been associated with vitiligo patients, but not all vitiligo patients suffer from conventional hearing loss. This sub-clinical gap might be able to be demonstrated using non-conventional tests.

\section{Aim}

The aim of this study was to assess hearing thresholds using both conventional pure tone audiometry (PTA) ( 0.25 to $8 \mathrm{kHz})$ and high frequency pure tone audiometry (10 and
$12.5 \mathrm{kHz}$ ) as well as outer hair cell functioning using Transient evoked Otoacoustic Emissions (TEOAEs) in vitiligo patients. We also wanted to correlate the audiometric findings with vitiligo duration and severity.

\section{Subjects and methods}

The study was carried out between October 2016 and June 2017 at the Audiology Unit outpatient clinic, Otorhinolaryngology department, and the Dermatology department in Kasr Al-Ainy hospital, Cairo University. The study was performed in accordance with the ethical standards of the Faculty of Medicine, Cairo University research committee and with the 1964 Helsinki declaration and its later amendments or comparable ethical standards. An informed oral consent was signed by all subjects for participation in the study.

This study included 75 subjects, 24 males and 51 females, with a mean age of $29.7 \pm 8.6$, ranging from 18 to 45 years, which were divided into two groups:

- A study group (cases), which included 50 adults suffering from vitiligo, 15 males and 35 females, whose mean age was $29.6 \pm 8.3$ years, ranging from $18-45$ years. They were recruited from those attending the dermatology outpatient clinic.

- A control group, which included 25 healthy adults, 9 males and 16 females, not complaining of vitiligo whose mean age was $29.9 \pm 9.2$ years, ranging from 18-45 years, well matched to the cases with respect to age and sex. Controls were recruited from those performing assessments at the audiology clinic.

There was no statistically significant difference between cases and controls regarding age $(t=0.123 ; p=0.902)$; or gender $\left(\chi^{2}=0.276 ; p=0.610\right)$. For age, the median was 30 with IQR $22-36$ in the cases, and $28(22-38)$ in the controls. The exclusion criteria were: previous ear surgery; familial hearing loss; ototoxic drug intake; chronic noise exposure; aged above 50 years; any disease or condition affecting hearing or balance, including other autoimmune diseases; and unilateral or asymmetric hearing loss.

Patients in this study were subjected to vitiligo diagnosis and scoring: 1) Clinical diagnosis of vitiligo by the dermatologist. 2) Scoring of severity and activity by the dermatologist.

a) Vitiligo area scoring index (VASI): Quantitative parametric score calculated using a formula to measure disease severity [22]. The percentage of vitiligo involvement is calculated in terms of hand units. One hand unit is approximately equivalent to $1 \%$ of the total body surface area. The degree of pigmentation is estimated to the nearest of one of the following percentages: $100 \%$ - complete depigmentation, no pigment is present; $90 \%$ - specks of pigment present; $75 \%$ - depigmented area exceeds the pigmented area; $50 \%$ - pigmented and depigmented areas are equal; $25 \%$ - pigmented area exceeds depigmented area; and 10\% - only specks of depigmentation present. The VASI for each body region is determined by the product of the area of vitiligo in hand units and the extent of depigmentation within each patch. The VASI 
is then derived by multiplying the values assessed for the vitiligo involvement by the percentage of affected skin for each body site and summing the values of all body sites together: VASI $=\sum[$ HAND UNITS $] \times[$ RESIDUAL DEPIGMENTATION] [23,24].

b) Vitiligo disease activity score (VIDA): Six-point scale to determine the activity of vitiligo [25]. An individual's own opinion is the base of the VIDA score. Grading is as follows. VIDA Score +4 : activity for 6 weeks or less; +3 : activity for 6 weeks to 3 months; 2 : activity for 3-6 months; +1: activity for 6-12 months; 0 : stable for at least 1 year; and -1 : stable for at least 1 year with spontaneous repigmentation [23].

Each participant was subjected to 1) Detailed history taking. 2) Otologic examination including otoscopy and tuning fork tests. 3) Basic audiological evaluation in a soundtreated room, Amplisilence Model E, and Madsen orbiter 922 pure-tone audiometer (GN Otometrics, Denmark) calibrated according to ISO standards. Testing included: Pure tone audiometry (PTA):

- Air conduction in the frequency range $0.25-8 \mathrm{kHz}$. Extended high frequency audiometry was performed at 10 and $12.5 \mathrm{kHz}$.

- Bone conduction in the frequency range $0.5-4 \mathrm{kHz}$.

According to the conventional PTA $(0.25$ to $8 \mathrm{kHz})$, normal hearing was classified as ears with PTA average up to 25 dBHL; mild SNHL: ears with PTA average 26-40 dBHL; moderate SNHL: ears with PTA average 41-55 dBHL; moderately severe SNHL: ears with PTA average 56-70 dBHL; severe SNHL: ears with PTA average: 71-90 dBHL; profound SNHL: ears with PTA average: 91+ dBHL [26]. There was no indication for ABR testing to exclude any retrocochlear lesion, i.e. all patients included in the study had symmetric hearing levels.

Tympanometry used a Madsen Zodiac 901 middle ear analyzer (GN Otometrics, Denmark), calibrated according to ISO standards, and included single frequency tympanometry with a $226 \mathrm{~Hz}$ probe tone. All participants had bilateral type A tympanograms reflecting normal middle ear pressure.

Transient evoked otoacoustic emissions (TEOAEs) were measured using a $100 \mu$ s click stimulus at $80 \mathrm{dBSPL}$, band pass filtered 0.3 to $5 \mathrm{kHz}$, at a rate of $66 \mathrm{~Hz}$. Noise level was below $50 \mathrm{~dB}$ SPL. 1000 averages were collected to judge the response. Responses were recorded in two buffers (A \& B) and averaged separately. The average amplitude of these two waveforms presented the overall echo level in dBSPL. The software determined the amplitude of TEOAE in five frequency bands $(1,2,3,4$, and $5 \mathrm{kHz})$. Signal to noise ratio (SNR) was computed for each frequency band. In addition, the reproducibility of the TEOAE was tested by the correlation between the signals from the two buffers. All responses were stored for analyses. TEOAE were considered present if the whole reproducibility was ${ }^{3} 50 \%$ according to Kemp [27]. The pass criteria were response $S N R \geq 3 \mathrm{~dB}$ with reproducibility $\geq 70 \%$ in at least three frequencies with overall $\mathrm{SNR} \geq 6 \mathrm{~dB}$ and overall reproducibility $\geq 70 \%$. A partial pass criterion was if the whole reproducibility was $50-70 \%$.

\section{Statistical analyses}

Data was coded and entered using the statistical package SPSS (Statistical Package for the Social Sciences) version 24. Quantitative data was summarized using mean, standard deviation, median, interquartile range, minimum and maximum; for categorical data frequency (count) and relative frequency (percentage) were used. Comparisons between two groups were done using unpaired $t$-tests. Comparisons between more than two groups were done using a Kruskal-Wallis test for non-parametric data. For comparing categorical data, a Chi square $\left(\mathrm{c}^{2}\right)$ test was performed. An Exact test was used instead when the expected frequency was less than 5 . Correlations between quantitative variables were done using Pearson correlation coefficient. $P$-values less than 0.05 were considered as statistically significant.

\section{Results}

The mean duration of vitiligo in the cases of this study was $5.7 \pm 5.5$ years, ranging from 0.04 to 30 years. The mean VASI score in the cases was $6.3 \pm 10.0$ ranging from 0.003 to 43. Assessed by VIDA scale, 2 cases were VIDA - $1 ; 3$ were VIDA $0 ; 2$ cases were VIDA+1; 7 cases were VIDA+2; 11 cases were VIDA+3; and 25 cases were VIDA+4.

\section{Audiometry}

All controls were bilaterally normal on conventional PTA $(0.25-8 \mathrm{kHz})$. For the vitiligo patients, conventional PTA $(0.25-8 \mathrm{kHz})$ revealed $38 / 50$ patients $(76 \%)$ with bilaterally normal hearing and $12 / 50$ patients (24\%) had sensorineural hearing loss (SNHL) - bilateral in 5 patients $(10 \%)$ and unilateral in 7 patients (14\%) (5 right; 2 left). Hearing loss involved $4 \mathrm{kHz}$ only in 3 patients: bilateral in 1 patient, unilateral in 2 patients (left). Hearing loss involved $8 \mathrm{kHz}$ only in 9 patients: bilateral in 3 patients, unilateral in 5 patients (4 right; 1 left). Hearing loss involved 4 and $8 \mathrm{kHz}$ in the right ear only in 2 patients.

Patients had high frequency hearing loss: mild at $4 \mathrm{kHz}$, ranging from mild to moderately severe at $8 \mathrm{kHz}$. Although the cases showed a statistically significant worse PTA thresholds at $1 \mathrm{kHz}$ in the right ears than the controls, the PTA threshold results at $1 \mathrm{kHz}$ were within the normal limits in all the vitiligo patients except for a mild hearing loss with a threshold of $30 \mathrm{dBHL}$ in one patient only, but many patients had a high normal threshold of $25 \mathrm{dBHL}$ which might have affected the mean result at $1 \mathrm{kHz}$. Although cases showed a statistically significant better PTA thresholds at $2 \mathrm{kHz}$ in the left ears than the controls, the PTA threshold results at $2 \mathrm{kHz}$ were within normal limits in the vitiligo patients (Table 1).

The cases showed a statistically significant worse EHF PTA thresholds at $10 \mathrm{kHz}$ and $12.5 \mathrm{kHz}$ than the controls (Table 1). EHF audiometry showed hearing loss in the majority $45 / 50$ (90\%) of the vitiligo patients. It was bilateral in $34 / 50$ patients $(68 \%)$ while unilateral in $11 / 50$ patients (22\%) (2 right, 9 left). Patients had high frequency hearing loss ranging from mild to severe at the extended high frequencies. Of the 38 patients who had normal hearing thresholds in conventional $(0.25-8 \mathrm{kHz})$ audiometry, 
Table 1. Comparison between cases and controls regarding pure tone audiometry (conventional and high frequency) thresholds at all tested frequencies

\begin{tabular}{|c|c|c|c|c|c|c|c|c|c|c|c|}
\hline \multirow{2}{*}{\multicolumn{2}{|c|}{$\begin{array}{l}\text { PTA } \\
\text { Frequencies }\end{array}$}} & \multicolumn{5}{|c|}{ Cases $(n=50)$} & \multicolumn{3}{|c|}{ Controls $(n=25)$} & \multirow{2}{*}{$t$-value } & \multirow{2}{*}{$p$-value } \\
\hline & & Mean & SD & Min. & Max. & Mean & SD & Min. & Max. & & \\
\hline \multirow{8}{*}{ Right } & $250 \mathrm{~Hz}$ & 14.3 & 4.04 & 5 & 25 & 13 & 3.82 & 5 & 20 & 1.337 & 0.185 \\
\hline & $500 \mathrm{~Hz}$ & 15.1 & 4.79 & 10 & 25 & 13.2 & 3.79 & 5 & 20 & 1.729 & 0.088 \\
\hline & $1 \mathrm{kHz}$ & 16.5 & 5.18 & 5 & 30 & 13.6 & 3.39 & 10 & 20 & 2.538 & 0.013 \\
\hline & $2 \mathrm{kHz}$ & 13.3 & 4.36 & 5 & 25 & 13.2 & 4.76 & 5 & 20 & 0.091 & 0.928 \\
\hline & $4 \mathrm{kHz}$ & 16.3 & 7.75 & 5 & 40 & 14.4 & 5.27 & 5 & 20 & 1.104 & 0.273 \\
\hline & $8 \mathrm{kHz}$ & 20.2 & 12.16 & 5 & 65 & 16.4 & 5.31 & 5 & 25 & 1.489 & 0.141 \\
\hline & $10 \mathrm{kHz}$ & 35.1 & 14.79 & 10 & 85 & 22 & 6.29 & 5 & 30 & 4.229 & 0.000 \\
\hline & $12.5 \mathrm{kHz}$ & 35.7 & 16.26 & 10 & 85 & 24.6 & 5.39 & 10 & 35 & 3.314 & 0.001 \\
\hline \multirow{8}{*}{ Left } & $250 \mathrm{~Hz}$ & 14.4 & 4.81 & 5 & 25 & 13 & 2.89 & 10 & 20 & 1.338 & 0.185 \\
\hline & $500 \mathrm{~Hz}$ & 14.9 & 4.68 & 5 & 25 & 13.8 & 3.62 & 5 & 20 & 1.03 & 0.307 \\
\hline & $1 \mathrm{kHz}$ & 14.7 & 4.45 & 10 & 25 & 13 & 5 & 5 & 20 & 1.496 & 0.139 \\
\hline & $2 \mathrm{kHz}$ & 11.7 & 4.7 & 5 & 20 & 14 & 4.33 & 5 & 20 & -2.051 & 0.044 \\
\hline & $4 \mathrm{kHz}$ & 14.6 & 7.13 & 5 & 35 & 13.6 & 4.45 & 5 & 20 & 0.64 & 0.524 \\
\hline & $8 \mathrm{kHz}$ & 17.8 & 8.4 & 5 & 50 & 15.6 & 4.86 & 5 & 25 & 1.21 & 0.230 \\
\hline & $10 \mathrm{kHz}$ & 35 & 13.74 & 10 & 70 & 22.4 & 7.09 & 5 & 30 & 4.298 & 0.000 \\
\hline & $12.5 \mathrm{kHz}$ & 37.4 & 15.95 & 15 & 85 & 24.8 & 6.53 & 10 & 35 & 3.785 & 0.000 \\
\hline
\end{tabular}
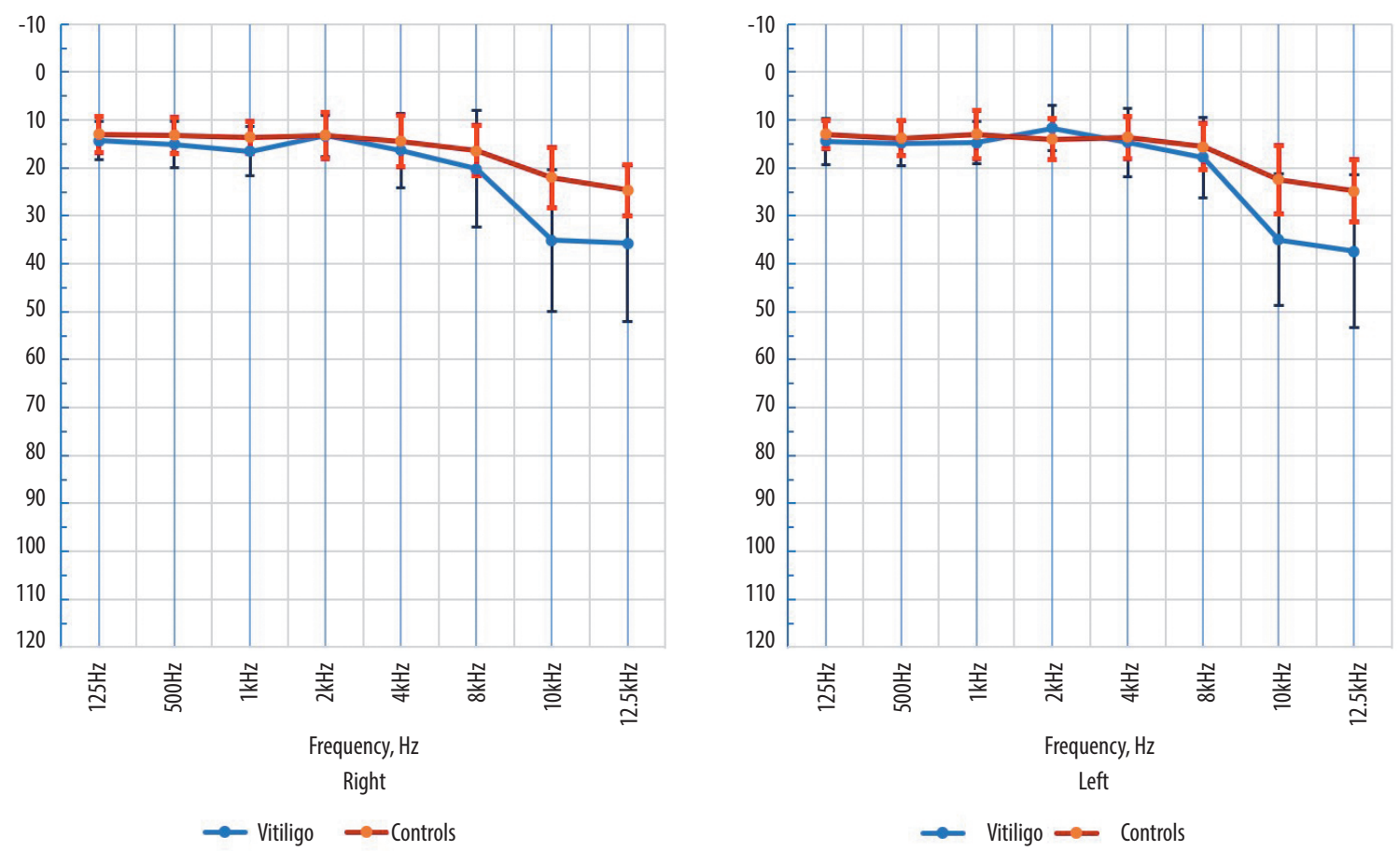

Figure 1. Hearing thresholds in $\mathrm{dB} \mathrm{HL}$ at different frequencies in the right and left ears of the vitiligo group (blue) and in controls (red) 
Table 2. Comparison between vitiligo patients with normal results in conventional pure tone audiometry $(0.25-8 \mathrm{kHz})$ and controls regarding the distribution of normal and abnormal extended high frequency results in the right and left ears

\begin{tabular}{|c|c|c|c|c|c|c|}
\hline \multirow[b]{2}{*}{ Right ear EHF PTA } & \multicolumn{2}{|c|}{ Vitiligo patients } & \multicolumn{2}{|c|}{ Controls } & \multirow[t]{2}{*}{$\chi^{2}$} & \multirow[t]{2}{*}{$p$-value } \\
\hline & no. & $\%$ & no. & $\%$ & & \\
\hline Normal & 13 & 34.2 & 18 & 72 & \multirow{3}{*}{8.616} & \multirow{3}{*}{0.005} \\
\hline Abnormal & 25 & 65.8 & 7 & 28 & & \\
\hline Total & 38 & 100 & 25 & 100 & & \\
\hline Left ear EHF PTA & no. & $\%$ & no. & $\%$ & \multirow{4}{*}{8.104} & \multirow{4}{*}{0.007} \\
\hline Normal & 8 & 21.1 & 14 & 56 & & \\
\hline Abnormal & 30 & 78.9 & 11 & 44 & & \\
\hline Total & 38 & 100 & 25 & 100 & & \\
\hline
\end{tabular}

5/38 (13\%) had within normal EHF hearing thresholds, while $33 / 38(87 \%)$ had high frequency hearing loss was bilateral in $22 / 38$ patients (58\%) and unilateral in $11 / 38$ (29\%).

Patients had mild to severe hearing loss at the extended high frequencies. In the controls, $7 / 25$ subjects (28\%) had unilateral abnormal EHF audiograms (1 right, 6 left). All were of a mild degree, and 13/25 (52\%) had bilateral normal EHF audiograms. Figure 1 shows hearing thresholds at different frequencies in the cases and in the controls.

The distribution of the EHF audiometric results in the 38 patients who had bilaterally normal hearing thresholds in conventional audiometry $(0.25-8 \mathrm{kHz})$ is shown in Figure 2. Table 2 shows the distribution of normal and abnormal results in the right and left ears of cases and the controls. The majority of the cases showed abnormal results: $66 \%$ and $79 \%$ in the right and left ears respectively, while the majority of the controls showed normal results in either right or left ears, with only $28 \%$ and $44 \%$ of the controls showing abnormal results in the right and left ears respectively. There was a statistically significant difference between the cases and controls regarding this distribution.

The right ears showed a greater percentage of hearing loss in EHF PTA (10 and $12.5 \mathrm{kHz}$ ). The distribution of normal and abnormal EHF PTA results in the different VIDA stages was not statistically significant in either the right or left ears $(p>0.05)$.

\section{Transient Evoked Otoacoustic Emission (TEOAE)}

All controls had bilaterally normal TEOAEs. Of the 38 vitiligo patients who had bilaterally normal hearing thresholds in conventional audiometry $(0.25-8 \mathrm{kHz})$, Figure 3 shows the TEOAE results. TEOAEs were preserved at all frequencies bilaterally in 21 patients (55\%) and abnormal in 17 of them (45\%). The abnormalities were: 1$)$ absent at all frequencies bilaterally in $1 / 38$ patients $(3 \%) ; 2$ ) preserved at all frequencies unilaterally in 9 patients $(24 \%)$ ( 4 in the right ear and 5 in the left); 3 ) absent at some frequencies bilaterally (partial pass response) in $7 / 38$ patients (18\%).

The overall reproducibility was $85 \pm 17 \%$ (right ears) and $87 \pm 20 \%$ (left ears) in the cases compared to $89 \pm 10 \%$ and $86 \pm 10 \%$ in the respective ears of the controls, but

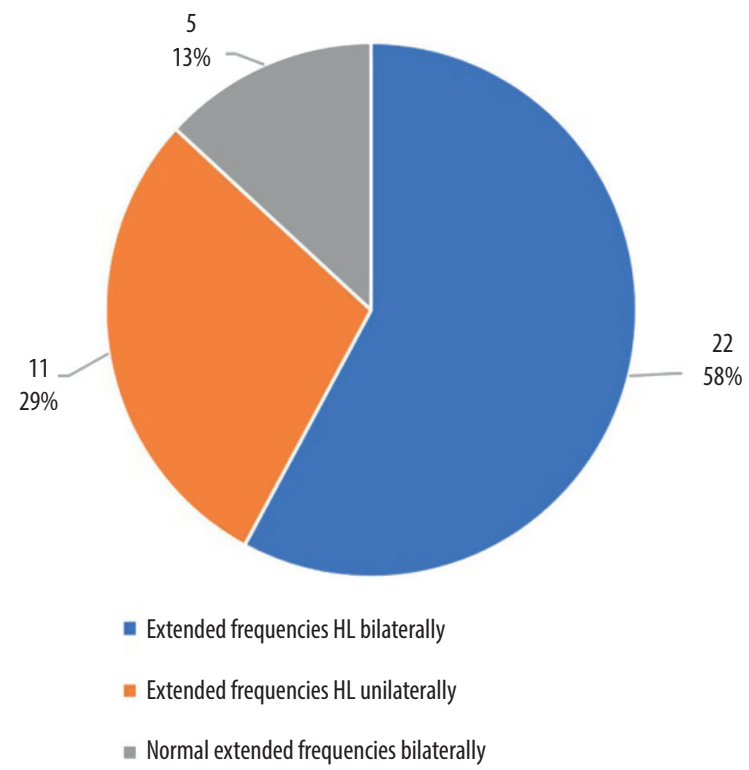

Figure 2. Extended frequency hearing loss $(\mathrm{HL})$ - based on results for 10 and $12.5 \mathrm{kHz}$ - in 38 patients who had bilaterally normal hearing thresholds in conventional pure tone audiometry $(0.25$ to $8 \mathrm{kHz})$

the differences were not statistically significant. There was a statistically significant difference between the cases who had bilaterally normal hearing thresholds in conventional audiometry $(0.25-8 \mathrm{kHz})$ in the right and left ears, and controls regarding the TEOAE SNR at $5 \mathrm{kHz}$ in the right ears and left ears (Table 3).

Of the 38 vitiligo patients (76 ears) who had bilaterally normal hearing thresholds in conventional audiometry $(0.25-8 \mathrm{kHz}), 34$ had abnormal OAEs, and 42 had normal OAEs. The majority $(26 / 34)(76 \%)$ of ears with abnormal OAEs had EHF PTA hearing loss, and the majority (29/42) $(69 \%)$ of ears with normal OAEs had EHF PTA hearing loss, and this distribution was not statistically significant $\left(\chi^{2}=0.518 ; p=0.607\right)$.

There was a statistically significant positive correlation between age and PTA at all tested frequencies, in both the vitiligo group and in the controls $(p<0.05)$. 
Table 3. Comparison between normal hearing vitiligo patients (according to conventional audiometry, $0.25-8 \mathrm{kHz}$ ) and controls regarding transient otoacoustic emissions (TEOAEs)

\begin{tabular}{|c|c|c|c|c|c|c|c|}
\hline & \multirow{2}{*}{ TEOAE } & \multicolumn{2}{|c|}{ Cases $(n=38)$} & \multicolumn{2}{|c|}{ Controls $(n=25)$} & \multirow{2}{*}{$t$-value } & \multirow{2}{*}{$p$-value } \\
\hline & & Mean & SD & Mean & SD & & \\
\hline \multirow{8}{*}{ Right } & $1 \mathrm{kHz}$ & 10.45 & 6.14 & 11.93 & 4.84 & -1.012 & 0.316 \\
\hline & $2 \mathrm{kHz}$ & 15.72 & 5.39 & 15.47 & 4.25 & 0.193 & 0.847 \\
\hline & $3 \mathrm{kHz}$ & 12.38 & 5.99 & 12.72 & 4.52 & -0.242 & 0.81 \\
\hline & $4 \mathrm{kHz}$ & 9.09 & 5.36 & 10.43 & 4.43 & -1.033 & 0.306 \\
\hline & $5 \mathrm{kHz}$ & 1.64 & 6.6 & 5.89 & 3.16 & -2.992 & 0.004 \\
\hline & Overall response (SPL) & 15.17 & 6.39 & 17.9 & 4.4 & -1.862 & 0.067 \\
\hline & Overall reproducibility (\%) & 84.63 & 17.17 & 88.66 & 10.03 & -1.057 & 0.295 \\
\hline & Mean AB value (SPL) & 15.69 & 5.96 & 18.22 & 4.38 & -1.819 & 0.074 \\
\hline \multirow{8}{*}{ Left } & $1 \mathrm{kHz}$ & 12.5 & 7.91 & 10.65 & 5.15 & 1.026 & 0.309 \\
\hline & $2 \mathrm{kHz}$ & 17.68 & 5.59 & 15.71 & 5.96 & 1.321 & 0.191 \\
\hline & $3 \mathrm{kHz}$ & 13.2 & 5.71 & 13.66 & 6.13 & -0.299 & 0.766 \\
\hline & $4 \mathrm{kHz}$ & 8.17 & 4.39 & 9.57 & 4.42 & -1.217 & 0.228 \\
\hline & $5 \mathrm{kHz}$ & 2.89 & 3.9 & 5.71 & 2.89 & -3.068 & 0.003 \\
\hline & Overall response (SPL) & 15.39 & 6.1 & 17.27 & 4.33 & -1.329 & 0.189 \\
\hline & Overall reproducibility (\%) & 86.72 & 20.4 & 86.34 & 10.35 & 0.085 & 0.933 \\
\hline & Mean $A B$ value (SPL) & 15.93 & 5.42 & 17.74 & 4.14 & -1.417 & 0.161 \\
\hline
\end{tabular}

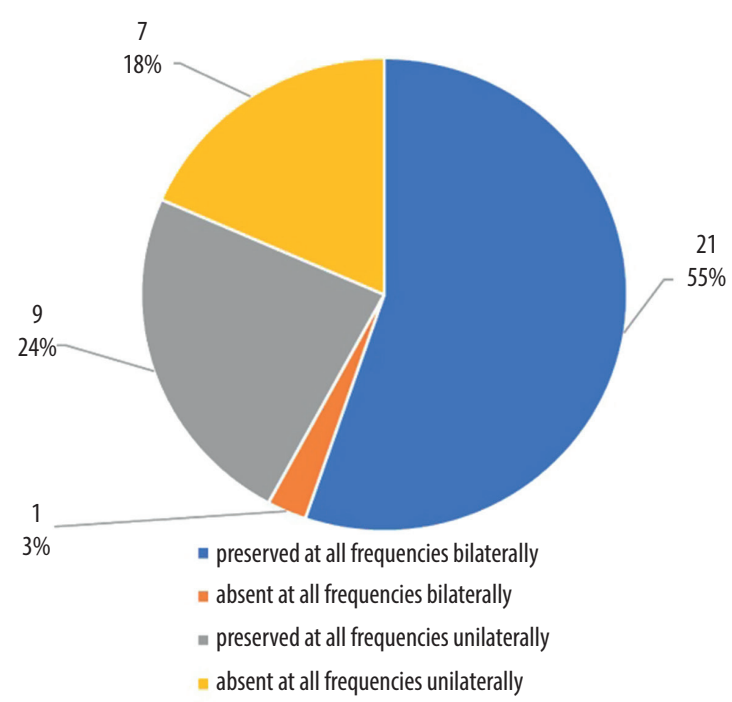

There was no statistically significant correlation between vitiligo duration and PTA. There was no statistically significant correlation between VASI and PTA (Table 4).

Age was not correlated with TEOAE either in the vitiligo group or in the controls ( $p>0.05)$, except for a negative correlation between age and TEOAE at $5 \mathrm{kHz}$ in the right ear $(p<0.05)$.

There was no statistically significant correlation between vitiligo duration, or VASI, with TEOAE (Table 5).

There was no statistically significant difference among the VIDA stages regarding the mean PTA thresholds results
Figure 3. Transient otoacoustic emission (TEOAE) results in 38 vitiligo patients who had bilaterally normal hearing thresholds in conventional pure tone audiometry $(0.25-8 \mathrm{kHz})$

in either the right or left ears $(p>0.05)$, or among the distribution of normal and abnormal conventional PTA results $(0.25-8 \mathrm{kHz})$ in the different VIDA stages in either the right or left ears $\chi^{2}=3.310 ; p=0.652$ (right PTA); $\chi^{2}=4.504 ; p=0.479$ (left PTA) - (data not shown, Kruskal-Wallis test). Figures 4 and 5 show the distribution of normal and abnormal conventional PTA $(0.25-8 \mathrm{kHz})$ results in the different VIDA stages in the right and left ears of the cases respectively.

There was no statistically significant difference among the VIDA stages regarding the mean TEOAE SNR, overall response, overall reproducibility, or the Mean AB value results in either the right or left ears $(p>0.05)$. 
Table 4. Correlation between vitiligo duration and VASI score at each pure tone threshold (conventional and high frequency) in the vitiligo patients

\begin{tabular}{|c|c|c|c|c|}
\hline \multicolumn{2}{|c|}{ PTA } & & \multirow{2}{*}{$\begin{array}{c}\begin{array}{c}\text { Vitiligo } \\
\text { Duration }\end{array} \\
-0.038\end{array}$} & \multirow{2}{*}{$\begin{array}{l}\text { VASI } \\
-0.129\end{array}$} \\
\hline \multirow{16}{*}{ Right } & \multirow{2}{*}{$250 \mathrm{~Hz}$} & $r$ & & \\
\hline & & $p$ & 0.793 & 0.371 \\
\hline & \multirow{2}{*}{$500 \mathrm{~Hz}$} & $r$ & 0.015 & -0.024 \\
\hline & & $p$ & 0.917 & 0.871 \\
\hline & \multirow{2}{*}{$1000 \mathrm{~Hz}$} & $r$ & 0.108 & -0.162 \\
\hline & & $p$ & 0.455 & 0.261 \\
\hline & \multirow{2}{*}{$2000 \mathrm{~Hz}$} & $r$ & 0.030 & -0.219 \\
\hline & & $p$ & 0.838 & 0.127 \\
\hline & \multirow{2}{*}{$4000 \mathrm{~Hz}$} & $r$ & 0.164 & 0.012 \\
\hline & & $p$ & 0.256 & 0.932 \\
\hline & \multirow{2}{*}{$8000 \mathrm{~Hz}$} & $r$ & 0.314 & 0.057 \\
\hline & & $p$ & 0.026 & 0.693 \\
\hline & \multirow{2}{*}{$10000 \mathrm{~Hz}$} & $r$ & 0.135 & 0.082 \\
\hline & & $p$ & 0.351 & 0.573 \\
\hline & \multirow{2}{*}{$12500 \mathrm{~Hz}$} & $r$ & 0.054 & 0.136 \\
\hline & & $p$ & 0.711 & 0.347 \\
\hline
\end{tabular}

\begin{tabular}{|c|c|c|c|c|}
\hline \multicolumn{2}{|c|}{ PTA } & & \multirow{2}{*}{$\begin{array}{c}\begin{array}{c}\text { Vitiligo } \\
\text { Duration }\end{array} \\
-0.037\end{array}$} & \multirow{2}{*}{$\begin{array}{c}\text { VASI } \\
-0.115\end{array}$} \\
\hline \multirow{16}{*}{ Left } & \multirow{2}{*}{$250 \mathrm{~Hz}$} & $r$ & & \\
\hline & & $p$ & 0.797 & 0.425 \\
\hline & \multirow{2}{*}{$500 \mathrm{~Hz}$} & $r$ & -0.010 & -0.188 \\
\hline & & $p$ & 0.946 & 0.192 \\
\hline & \multirow{2}{*}{$1000 \mathrm{~Hz}$} & $r$ & 0.111 & -0.152 \\
\hline & & $p$ & 0.441 & 0.294 \\
\hline & \multirow{2}{*}{$2000 \mathrm{~Hz}$} & $r$ & -0.022 & -0.150 \\
\hline & & $p$ & 0.882 & 0.299 \\
\hline & \multirow{2}{*}{$4000 \mathrm{~Hz}$} & $r$ & 0.141 & 0.032 \\
\hline & & $p$ & 0.328 & 0.826 \\
\hline & \multirow{2}{*}{$8000 \mathrm{~Hz}$} & $r$ & 0.070 & -0.037 \\
\hline & & $p$ & 0.629 & 0.800 \\
\hline & \multirow{2}{*}{$10000 \mathrm{~Hz}$} & $r$ & 0.086 & 0.079 \\
\hline & & $p$ & 0.552 & 0.583 \\
\hline & \multirow{2}{*}{$12500 \mathrm{~Hz}$} & $r$ & 0.144 & 0.099 \\
\hline & & $p$ & 0.317 & 0.493 \\
\hline
\end{tabular}

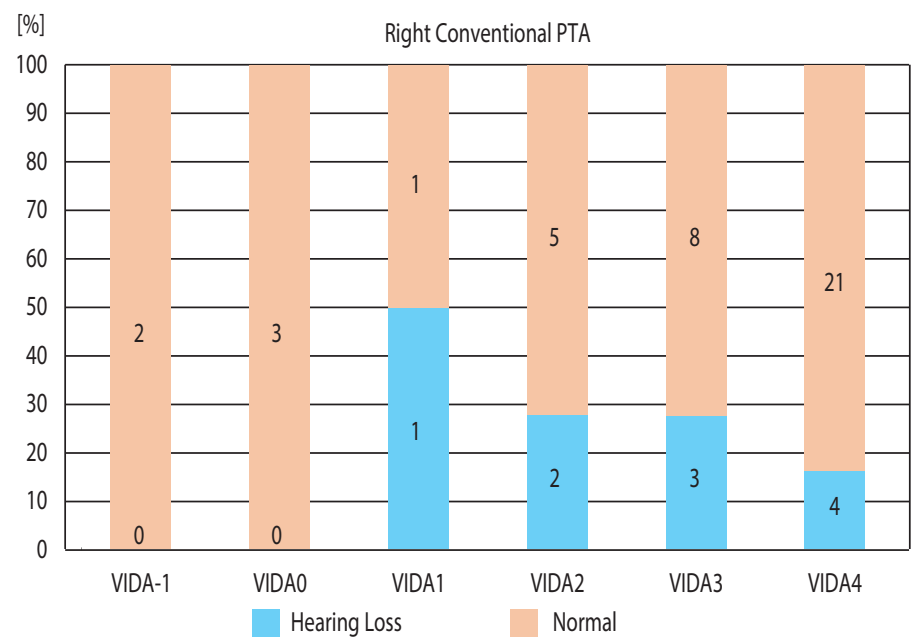

Figure 4. Percentages of normal (orange) and abnormal (blue) conventional PTA results $(0.25-8 \mathrm{kHz})$ in the right ears of the vitiligo group at different VIDA stages

There was no statistically significant difference among the distribution of normal and abnormal EHF PTA results $\chi^{2}=4.781 ; p=0.443$ (right); $\chi^{2}=3.102 ; p=0.684$ (left) (data not shown, Kruskal-Wallis test). Figures 6 and 7 show the distribution of normal and abnormal EHF PTA results in the different VIDA stages in the right and left ears of the cases.

Figures 8 and 9 show the distribution of normal and abnormal TEOAE results in the different VIDA stages in the right and left ears of the 38 normal hearing cases. There was no statistically significant difference among the different VIDA stages regarding the distribution of normal and abnormal TEOAE results in the right and left ears of the cases: $\chi^{2}=4.073 ; p=0.850$ (right); $\chi^{2}=2.736 ; p=0.950$ (left).

\section{Discussion}

\section{Audiometry}

Our PTA findings of the patients revealed that the majority $(76 \%)$ had bilaterally normal hearing thresholds, while $24 \%$ had high frequency hearing loss (bilateral in $10 \%$ and unilateral in 14\%). Hearing loss was mild at $4 \mathrm{kHz}$, and ranged from mild to moderately severe at $8 \mathrm{kHz}$. This reflects damage to the inner ear melanocytes in vitiligo patients.

Our PTA results are in agreement with Dawoud et al. [28] whose study revealed that $23 / 30(77 \%)$ of vitiligo patients 
Table 5. Correlation between vitiligo duration and VASI score in terms of transient otoacoustic emission (TEOAE) in the 38 vitiligo patients with normal hearing (according to conventional audiometry, $0.25-8 \mathrm{kHz}$ )

\begin{tabular}{|c|c|c|c|c|}
\hline & TEOAE & & Duration & VASI \\
\hline \multirow{16}{*}{ Right } & \multirow{2}{*}{$1 \mathrm{kHz}$} & $r$ & -0.155 & 0.086 \\
\hline & & $p$ & 0.289 & 0.557 \\
\hline & \multirow{2}{*}{$2 \mathrm{kHz}$} & $r$ & 0.034 & 0.081 \\
\hline & & $p$ & 0.817 & 0.579 \\
\hline & \multirow{2}{*}{$3 \mathrm{kHz}$} & $r$ & -0.101 & -0.192 \\
\hline & & $p$ & 0.489 & 0.185 \\
\hline & \multirow{2}{*}{$4 \mathrm{kHz}$} & $r$ & -0.179 & -0.148 \\
\hline & & $p$ & 0.219 & 0.312 \\
\hline & \multirow{2}{*}{$5 \mathrm{kHz}$} & $r$ & -0.091 & -0.032 \\
\hline & & $p$ & 0.535 & 0.826 \\
\hline & \multirow{2}{*}{$\begin{array}{c}\text { Overall } \\
\text { response (SPL) }\end{array}$} & $r$ & -0.155 & -0.100 \\
\hline & & $p$ & 0.282 & 0.490 \\
\hline & \multirow{2}{*}{$\begin{array}{l}\text { Overall } \\
\text { reproducibility } \\
(\%)\end{array}$} & $r$ & 0.011 & 0.103 \\
\hline & & $p$ & 0.942 & 0.478 \\
\hline & \multirow{2}{*}{$\begin{array}{c}\text { Mean AB value } \\
\text { (SPL) }\end{array}$} & $r$ & -0.167 & -0.119 \\
\hline & & $p$ & 0.245 & 0.409 \\
\hline
\end{tabular}

\begin{tabular}{|c|c|c|c|c|}
\hline & TEOAE & & Duration & VASI \\
\hline \multirow{16}{*}{ Left } & \multirow{2}{*}{$1 \mathrm{kHz}$} & $r$ & -0.010 & 0.118 \\
\hline & & $p$ & 0.944 & 0.424 \\
\hline & \multirow{2}{*}{$2 \mathrm{kHz}$} & $r$ & 0.068 & -0.036 \\
\hline & & $p$ & 0.647 & 0.807 \\
\hline & \multirow{2}{*}{$3 \mathrm{kHz}$} & $r$ & -0.006 & -0.235 \\
\hline & & $p$ & 0.965 & 0.108 \\
\hline & \multirow{2}{*}{$4 \mathrm{kHz}$} & $r$ & -0.137 & -0.095 \\
\hline & & $p$ & 0.355 & 0.521 \\
\hline & \multirow{2}{*}{$5 \mathrm{kHz}$} & $r$ & -0.147 & -0.127 \\
\hline & & $p$ & 0.320 & 0.389 \\
\hline & \multirow{2}{*}{$\begin{array}{c}\text { Overall } \\
\text { response (SPL) }\end{array}$} & $r$ & -0.233 & -0.152 \\
\hline & & $p$ & 0.104 & 0.291 \\
\hline & \multirow{2}{*}{$\begin{array}{c}\text { Overall } \\
\text { reproducibility } \\
(\%)\end{array}$} & $r$ & -0.192 & 0.037 \\
\hline & & $p$ & 0.182 & 0.796 \\
\hline & \multirow{2}{*}{$\begin{array}{c}\text { Mean } A B \text { value } \\
(\mathrm{SPL})\end{array}$} & $r$ & -0.223 & -0.184 \\
\hline & & $p$ & 0.119 & 0.202 \\
\hline
\end{tabular}
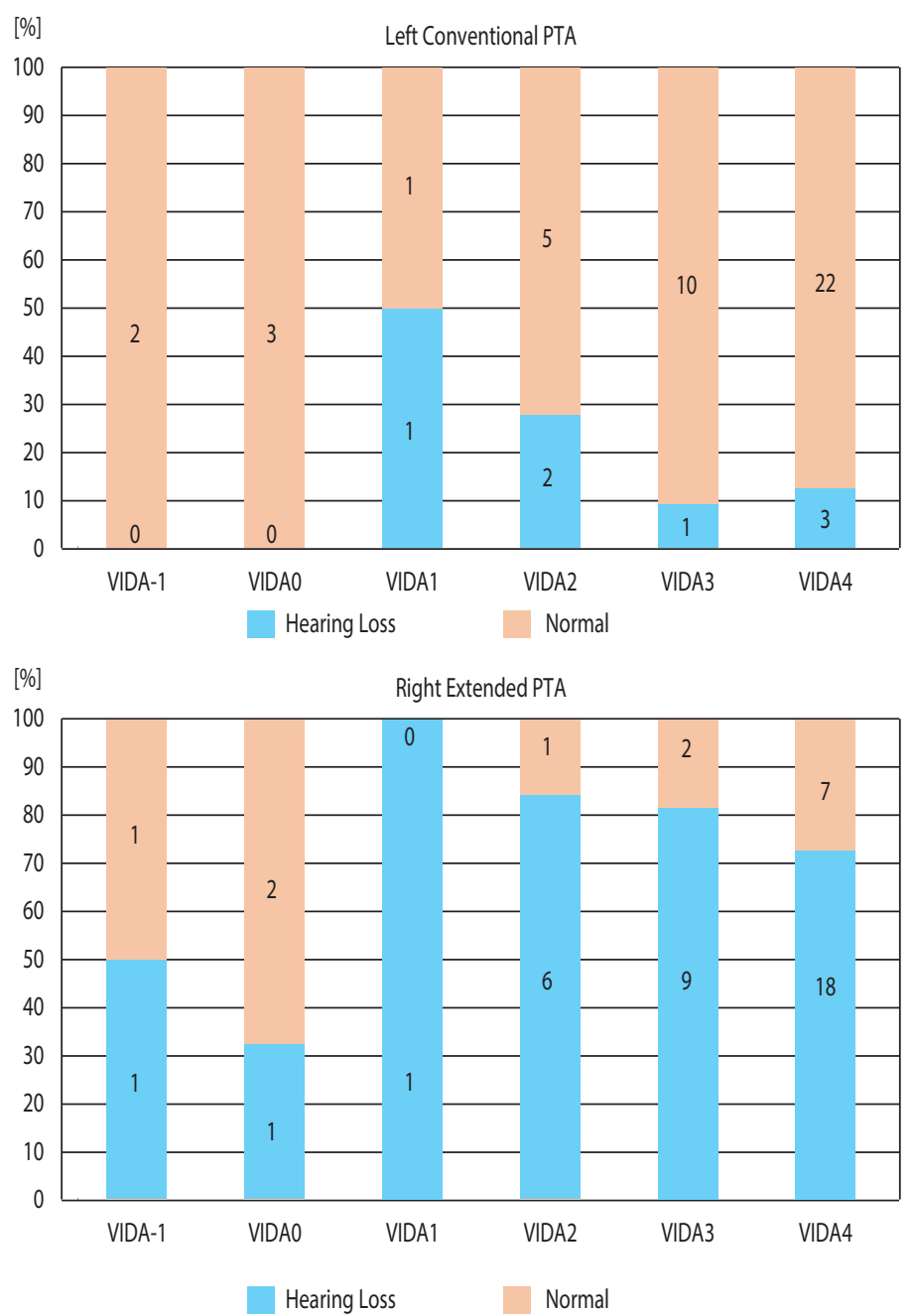

Figure 5. As for Figure 4 but for the left ear.

Figure 6. Percentages of normal (orange) and abnormal (blue) extended pure tone audiometry results in the right ears of the vitiligo group at different VIDA stages 

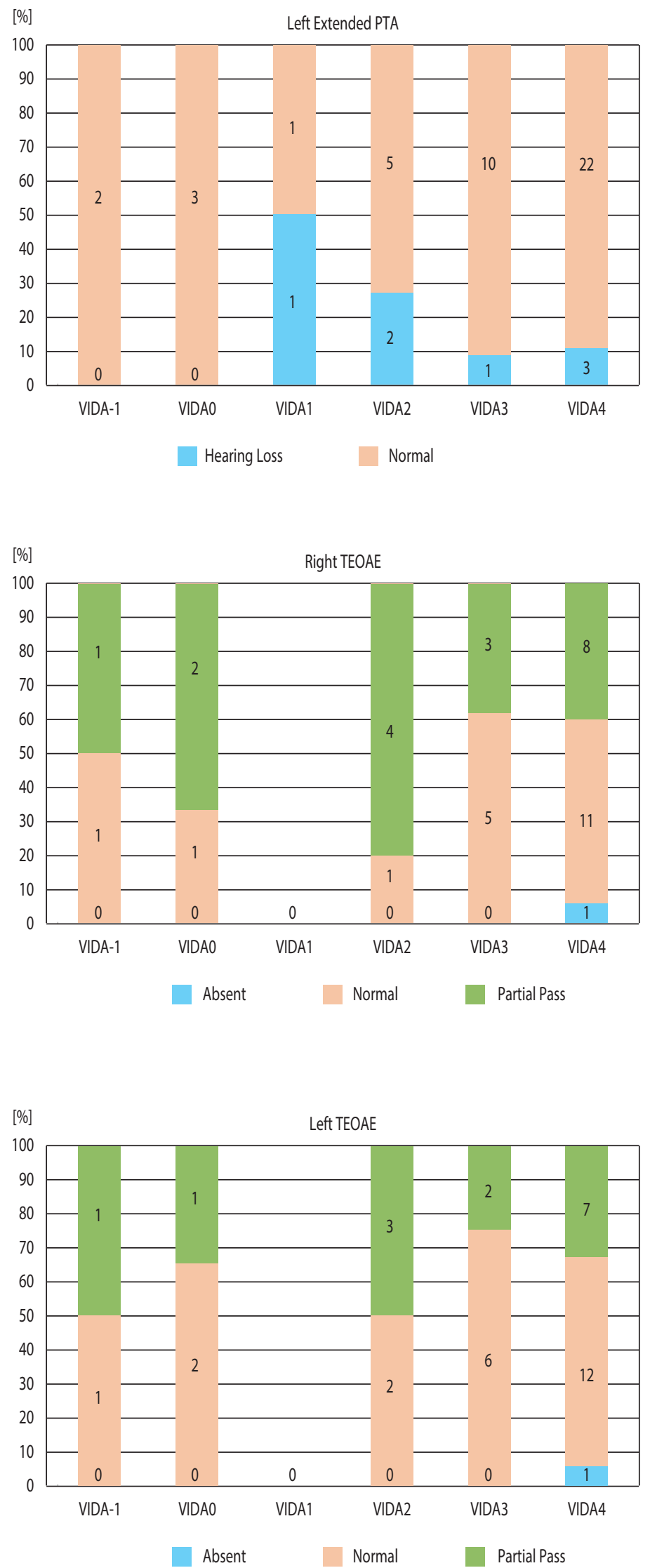

Figure 7. As for Figure 6, but for the left ear

Figure 8. Percentages of normal (orange) and partial passes (green) for transient otoacoustic emission (TEOAE) tests in the right ears of the vitiligo group at different VIDA stages. There was 1 case of no TEOAE response (blue) in the VIDA4 group

Figure 9. As for Figure 8 but for the left ear 
had normal PTA thresholds and 7/30 (23\%) patients had mild to moderate SNHL.

In comparison to our study, several studies have shown slightly higher percentage of SNHL in vitiligo patients. Sahrifian et al. [29] found high frequency SNHL in 19 of 50 patients $(38 \%)$, it was bilateral in $63 \%$, and in $11 \%$ only the left ear and in $26 \%$ only the right ear was involved. They noted that hearing loss was not seen at speech frequencies, and it was limited to only high frequencies, especially above $4 \mathrm{kHz}$, justifying the lack of hearing loss complaints by patients. Akay et al. [7] observed SNHL in $20 / 50$ patients $(40 \%)$ of the vitiligo cases and $16 \%$ of the controls, and the difference was statistically significant. There were 9 of the 20 patients who showed unilateral minimal hearing loss $(<30 \mathrm{~dB})$, while the other 11 demonstrated bilateral hearing loss $(>30 \mathrm{~dB})$ over a large range of frequencies $(2-8 \mathrm{kHz})$. Mahdi et al. [10] found statistically greater pure tone thresholds at 2,4 , and $8 \mathrm{kHz}$ in both ears of 8 patients out of 21 (38\%) ( $p \leq 0.05)$; 5 patients had generalized, 1 had total, and 2 had a segmental type of disease, and 3 had unilateral and 5 had bilateral SNHL. The pattern of hearing loss was in the range $2-8 \mathrm{kHz}$ in 3 (14\%) patients, was limited to $4-8 \mathrm{kHz}$ in another 3 , and was limited to $4 \mathrm{kHz}$ only in 2 others. Nevertheless, the PTA of all patients was still within the normal range. Their findings strengthen the hypothesis that an alteration of the inner ear pigment cells favor the occurrence of hypoacusis.

Fleissig et al. [2] found SNHL in $69 \%$ of vitiligo patients compared with $6 \%$ of the controls. This difference was statistically significant $(p=0.001)$. Some $25 \%$ of the cases suffered from moderate to severe SNHL. Vitiligo patients demonstrated a significantly higher prevalence of all degrees of SNHL compared with the controls $(p=0.002)$. When examining the audiogram shapes, the 'notch' shape was the most frequent type among vitiligo patients and was significantly more common in vitiligo patients $(50 \%)$ compared with controls $(12.5 \%),(p=0.021)$ with no history of noise exposure.

In comparison to our study, several studies have shown a lower percentage of SNHL in vitiligo patients. Aydogan et al. [9] found sensorineural hypoacusis in 8 patients (14\%) with generalized vitiligo and VIDA score 3 , who previously had no complaint of any hearing impairment. There were 2 of the 8 patients who showed unilateral minimal hearing loss $(>30 \mathrm{~dB})$ at only high frequencies $(4-8 \mathrm{kHz})$, while the other six demonstrated bilateral hearing loss $(>30 \mathrm{~dB})$ over a large range of frequencies $(2-8 \mathrm{kHz})$. The findings in the control subjects were all within normal limits $(p=0.006)$. Tosti et al. [11] examined 50 patients with vitiligo and auditory abnormalities were detected in $16 \%$ of them. All had SNHL and they were affected by generalized vitiligo. They attributed their findings to the involvement of the inner ear melanocytes which are thought to prevent damage to hair cells of the inner ear from environmental ototoxic agents. They said that this hypothesis was also supported by the finding that black-skinned persons are less commonly affected by noise-induced hypoacusis than are white skinned persons who live in the same habitat [30].

Gill and Salt [31] found that in pigmented animals the endolymph $\mathrm{Ca}^{2+}$ tended to increase from base to apex of the cochlea, while the endocochlear potential systematically decreased towards the apex. In contrast, no significant $\mathrm{Ca}^{2+}$ gradient was found in albinos and the endocochlear potential decline was far less. Their results confirm the involvement of melanin in the active transport of $\mathrm{Ca}^{2+}$ into endolymph.

Gopal et al. [32] found hypoacusis in $20 \%$ of their vitiligo patients compared to $2 \%$ of the controls. The majority of patients with hypoacusis (87\%) had a sensorineural type of impairment, while the rest had conductive hearing loss.

But a study by Al-Mutairi et al. [33] showed that $22 \%$ of their vitiligo cases and $18 \%$ of the controls showed hypoacusis. This difference was not statistically significant. On the other hand, El-Gohary et al. [34] found no significant difference in PTA thresholds between control and vitiligo groups at any frequency from 0.25 to $8 \mathrm{kHz}$.

The audiometry results of different studies are puzzling. Fleissig et al. [2] stated that the dissimilarity in the results of different studies may be explained as a consequence of the different ethnicities of the populations examined. Hong et al. [35] and Sharma et al. [15] had similar results to each other when testing populations from the Far East; similarly Ardic et al. [13] and Aslan et al. [8] found similar figures after testing a Turkish population. The number of melanosomes in inner ear melanocytes varies between ethnic groups and individuals in accordance with skin pigmentation [36]. Escalante-Ugalde et al. [37] could not find a significant association with vitiligo in their patients who were dark-skinned.

In the current study, EHF audiometry showed hearing loss in the majority 45/50 (90\%) of the vitiligo patients. It was bilateral in $34 / 50$ patients $(68 \%)$ while unilateral in $11 / 50$ patients (22\%). Patients had high frequency hearing loss ranging from mild to severe at the extended high frequencies. The cases showed a statistically significant worse extended PTA thresholds at $10 \mathrm{kHz}$ and $12.5 \mathrm{kHz}$ compared to the controls. Of the 38 patients who had normal hearing thresholds in conventional audiometry $(0.25-8 \mathrm{kHz})$, $5 / 38$ (13\%) had within normal extended hearing thresholds, while $33 / 38$ (87\%) had extended hearing loss, which was bilateral in $22 / 38$ patients $(58 \%)$ and unilateral in $11 / 38$ (29\%). This reflects the importance of EHF testing to detect subclinical inner hair cells involvement of the basal turn of the cochlea.

Aslan et al. [8] found that SNHL was present in 36\% of ears using conventional pure tone audiometry $(0.25-8 \mathrm{kHz})$, but in $59 \%$ of the ears at high frequencies $(10-12.5 \mathrm{kHz})$. There was audiometric hearing loss in 12 patients, but only four of them complained of hearing loss. The authors say that the reason for a higher incidence of hearing loss in their study might have been due to longer duration of disease in their patients than in other previous studies, or that the skin types of their patients were types 2 and 3 (68\% had type $3 ; 32 \%$ had type 2 ).

Ardic et al. [13] found that the pure tone thresholds of their vitiligo group were significantly lower than the control group, starting from $4 \mathrm{kHz}$ up to $16 \mathrm{kHz}$. Fleissig et al. [2] found that the mean pure tone hearing thresholds in 
the range $0.25-8 \mathrm{kHz}$ was significantly higher in each ear compared with the matched control group $(p=0.023)$, levels that caused significant functional deficit. A marginal statistical difference was found when the mean pure tone hearing thresholds in the range $0.25-12 \mathrm{kHz}$ were compared between the groups. No difference was noted when the mean pure tone hearing thresholds in the range $0.5-2 \mathrm{kHz}$ and speech reception thresholds were compared between the groups.

Shalaby et al. [38] showed that mean pure tone thresholds for $0.25-16 \mathrm{kHz}$ were more elevated in the study group than in the control group, but this difference was not statistically significant. In terms of hearing sensitivity, some $15 \%$ of the patients with vitiligo who demonstrated audiologic changes were symptom free. We can therefore assume that the hearing organ is minimally affected and hearing loss is usually not detected by the patient, although some vitiligo patients who had near-normal pure tone thresholds in conventional audiometry $(0.25-8 \mathrm{kHz})$ showed deficits at extended high frequency.

\section{Transient Evoked Otoacoustic Emission (TEOAE)}

Of the 38 normal hearing patients in conventional audiometry $(0.25-8 \mathrm{kHz})$ in our current study, TEOAEs were preserved at all frequencies bilaterally in 55\% and abnormal in $45 \%$. They were mostly absent at some frequencies (partial pass response) bilaterally or unilaterally, reflecting outer hair cells dysfunction in the cochlea. They were absent at all frequencies bilaterally in 3\% of the normal hearing patients; preserved at all frequencies unilaterally and absent at some frequencies unilaterally in $24 \%$ of the normal hearing patients; and absent at some frequencies bilaterally (partial pass response) in $18 \%$ of the normal hearing patients. In the current study, the cases showed a statistically significant decreased TEOAE SNR at $5 \mathrm{kHz}$ in the right ears and left ears compared to the controls. It seems that outer hair cell dysfunction involves the high frequency region in the basal cochlear turn. This reflects the importance of monitoring to provide preclinical evidence of hearing damage, even before evidence of hearing loss is seen in conventional tests.

Moreover, the majority of vitiligo patients in our study had EHF hearing loss irrespective of their OAE result, which seems logical as both tests assess different parts of the cochlea - the inner and outer hair cells respectively. This emphasises the need to perform both tests to assess any subclinical cochlear effect in vitiligo patients.

In agreement with our TEOAE results, Anbar et al. [3] examined 53 patients with vitiligo and normal audiograms, and $60 \%$ of them had cochlear dysfunction based on DPOAEs, often bilaterally, whereas their control group showed no abnormality.

Shalaby [38] found a significant decrease in reproducibility of TEOAE in the vitiligo group compared with the control group. The reproducibility was $33.3 \%$ in the vitiligo group compared to $98 \%$ in the control group. Significant differences in TEOAE at different frequencies were also detected.
El-Gohary et al. [34] also found smaller SNRs in the $4 \mathrm{kHz}$ band and a higher percentage of abnormal TEOAE findings in the form of partial pass responses (35\%).

In the Fleissig et al. [2] study, 2 patients in the vitiligo group failed the TEOAE test, with one of them having a normal audiogram. Their findings may imply that the prevalence of cochlear impairment among vitiligo patients is higher than estimated by audiogram alone and even patients with normal audiograms may need further evaluation by TEOAE.

Aslan et al. [8], Fleissig et al. [2], and Angrisani et al. [39] found failure only at higher frequencies, 3 or $4 \mathrm{kHz}$, in vitiligo patients (with 70 or $75 \%$ reproducibility and a response criterion of three frequencies at $3 \mathrm{~dB}$ or greater above the noise floor). Angrisani et al. reported that in a third of the cases they examined, suppression of OAEs was absent when white noise was presented to the contralateral ear (to test the function of the efferent pathways). Their findings showed that $67 \%$ of the vitiligo patients with normal audiometry results had partial or total loss, among them $65 \%$ with bilateral failure mostly at high frequencies (63\%).

\section{Age}

There was a statistically significant positive correlation between age and PTA at all tested frequencies, in both the vitiligo group and in the controls $(p<0.05)$, so although cochlear dysfunction was worse in older patients, it was not possible to relate cochlear dysfunction to vitiligo, even when presbycusis was excluded (age range from 18 to 45 years).

Age was not correlated with TEOAE in both the vitiligo group and in the controls $(p>0.05)$, except that TEOAE at $5 \mathrm{kHz}$ in the right ear was worse at older ages.

Vitiligo patients with SNHL tended to be older and have late onset vitiligo. Fleissig et al. [2] found age to be a factor in SNHL among vitiligo patients, as vitiligo patients older than 20 had a higher mean pure tone hearing threshold than the control group, whereas no differences in mean pure tone hearing thresholds were found between patients under 20 years and healthy controls under 20 , indicating that SNHL in vitiligo patients occurs at an older age and may worsen with age. Their data revealed a tendency towards increased severity of SNHL in older vitiligo patients and late onset of the condition.

Al-Mutairi et al. [33] concluded that, contrary to observations in early onset vitiligo, late onset vitiligo did not seem to be associated with audiological abnormalities.

\section{Duration of vitiligo}

In the current study, vitiligo duration did not have any effect on cochlear function, not being correlated with either hearing loss or with TEOAE. It seems that once the inner ear melanocytes get damaged, cochlea dysfunction occurs irrespective of time.

In agreement with our study, Iannella [1] stated that audiometric findings of no statistical correlation between age, duration of disease, and sex can be explained by the hypothesis that otic melanocytes are damaged at the early stage 
of vitiligo and then become stabilized. Aydogan et al. [9], Gopal et al. [32], and El-Gohary et al. [34] did not find any relationship between hearing loss and duration of vitiligo.

However, Arya et al. [40], Aslan et al. [8], Ardic et al. [13], and Hong et al. [35] found a statistically significant association between hearing loss and longer duration of the disease. Schrott and Spoendlin [41] stated that, over a long time, a hypopigmentation disorder may lead to degeneration of the outer hair cells, beginning from the basal turn of the cochlea, whereas inner hair cells remain structurally and functionally intact.

In comparison to our study, Bassiouny et al. [42] found that the mean of the TEOAE whole reproducibility percentage was $49 \%$ for vitiligo group with more than 10 years duration.

\section{Vitiligo severity}

VASI was not correlated with hearing loss nor with TEOAE. There was no statistically significant difference among the VIDA stages regarding mean PTA threshold in either the right or left ears $(p>0.05)$. Although there was a greater percentage of hearing loss in more severe degrees of vitiligo (according to VIDA), the distribution of normal and abnormal conventional PTA $(0.25-8 \mathrm{kHz})$ results among the different VIDA stages was not statistically significant in either the right or left ears) ( $p>0.05)$.

The right ears showed greater percentage of hearing loss in EHF PTA (10 and $12.5 \mathrm{kHz}$ ). The distribution of normal and abnormal extended PTA results in the different VIDA stages of severity was not statistically significant in either the right or left ears $(p>0.05)$. There was no statistically significant difference among the VIDA stages regarding the mean TEOAE SNR results in either the right or left ears $(p>0.05)$. The distribution of normal and abnormal TEOAE results in the different VIDA stages was not statistically significant in either the right or left ears $(p>0.05)$. It seems that once the inner ear melanocytes get destroyed, the cochlea shows dysfunction, irrespective of involvement of the severity of involvement of other areas of the body such as the skin.

In agreement with our study, Shalaby et al. [38] found no relation between duration, severity of the disease (number of affected sites), and any audiological parameter. Mahdi et al. [10] found no differences in the hearing loss among all clinical types of vitiligo, although hypoacusis prevalence was higher in vitiligo vulgaris patients than in the other clinical types (but not statistically significant, $p=0.407$ ).

Cochlear function was affected equally in both generalized and localized vitiligo subgroups [38]. However, Anbar et al. [3] demonstrated that bilateral cochlear dysfunction was common in segmental and non-segmental vitiligo subtypes of the disease. Gopal et al. [32] found that $80 \%$ of patients with hypoacusis had non-segmental vitiligo. Hong et al. [35] found non-segmental vitiligo to be associated with hypoacusis.

Aslan et al. [8] found a correlation between hearing loss in vitiligo patients and body percentage involved (an increasing rate of statistically significant hearing loss was observed as the body percentage of vitiligo exceeded 10\%).

Sharma et al. [15] found generalized vitiligo to be a risk factor for SNHL. Patients with mucosal involvement as the primary site of onset demonstrated a negative association with SNHL (i.e. patients with mucosal involvement as the primary site of onset had normal hearing). Fleissig et al. [2] did not see any association between SNHL and various clinical parameters of vitiligo.

\section{Conclusion}

Conventional pure tone audiometry $(0.25-8 \mathrm{kHz})$ revealed that only about one-quarter of vitiligo patients had hearing loss. But using extended high frequency audiometry, the majority of normal hearing patients showed hearing loss, mostly bilateral. Using transient evoked otoacoustic emissions, about half of the normal hearing patients showed abnormal results, either bilateral or unilateral. The audiometric findings of the vitiligo group, and the statistically significant differences from the control group, suggest a subclinical involvement of the outer and inner hair cells of the cochlea in the basal turn, probably related to the vitiligo condition, but not influenced by vitiligo duration or severity. We recommend the use of extended high frequency audiometry and otoacoustic emission testing for early detection of inner ear involvement in vitiligo patients.

\section{References}

1. Iannella G, Greco A, Didona D, Didona B, Granata G, Manno A, Pasquariello B, Magliul G. Vitiligo: pathogenesis, clinical variants and treatment approaches. Autoimmunity Reviews, 2016; 15(4): 335-43.

2. Fleissig E, Gross M, Ophir I, Elidan J, Bdolah-Abram T, Ingber A. Risk of sensorineural hearing loss in patients with vitiligo. Audiol Neurootol, 2013; 18: 240-6.

3. Anbar TS, El-Badry MM, McGrath JA, Abdel-Azim ES. Most individuals with either segmental or non-segmental vitiligo display evidence of bilateral cochlear dysfunction. Br J Dermatol, 2015; 172(2): 406-11.

4. Dahir AM, Thomsen SF. Comorbidities in vitiligo: comprehensive review. Int J Dermatol, 2018; 57(10): 1157-64.

5. McGinness J, Corry P, Proctor P. Amorphous semiconductor switching in melanins. Science, 1974; 183(4127): 853-5.
6. Tachibana M. Cochlear melanocytes and MITF signaling. J Investig Dermatol Symp Proc, 2001; 6(1): 95-8.

7. Akay BN, Bozkir M, Anadolu Y, Gullu S. Epidemiology of vitiligo, associated autoimmune diseases and audiological abnormalities: Ankara study of 80 patients in Turkey. J Eur Acad Dermatol Venereol, 2010; 24: 1144-50.

8. Aslan S, Serarslan G, Teksoz E, Dagli S. Audiological and transient evoked otoacoustic emission findings in patients with vitiligo. Otolaryngol Head Neck Surg, 2010; 142: 409-14.

9. Aydogan K, Turan OF, Onart S, Karadogan SK, Tunali S. Audiological abnormalities in patients with vitiligo. Clin Exp Dermatol, 2006; 31: 110-13.

10. Mahdi P, Rouzbahani M, Amali A, Rezaii Khiabanlu S, Kamali M. Audiological manifestations in vitiligo patients. Iran J Otorhinolaryngol, 2012; 24: 35-40. 
11. Tosti A, Bardazzi F, Tosti G, Monti L. Audiologic abnormalities in cases of vitiligo. J Am Acad Dermatol, 1987; 17: 230-3.

12. Nikiforidis GC, Tsambaos DG, Karamitsos DS et al. Abnormalities of the auditory brainstem response in vitiligo. Scand Audiol, 1993; 22: 97-100.

13. Ozuer MZ, Sahiner T, Aktan S et al. Auditory evoked potentials in vitiligo patients. Scand Audiol, 1998; 27: 255-8.

14. Ardic FN, Aktan S, Kara CO, Sanli B. High-frequency hearing and reflex latency in patients with pigment disorder. Am J Otol, 1998; 19: 365-9.

15. Sharma L, Bhawan R, Jain RK. Hypoacusis in vitiligo. Indian J Dermatol Venereol Leprol, 2004; 70: 162-4.

16. Steel KP, Barkway C. Another role for melanocytes: their importance for normal stria vascularis development in mammalian inner ear. Development, 1989; 107: 453-63.

17. Tachibana M. Sound needs sound melanocytes to be heard. Pigment Cell Res, 1999; 12: 344-54.

18. Ortonne JP, Bahadoran P et al. Hypomelanoses and hypermelanosis. In: Fitzpatrick's Dermatology in General Medicine (Freedberg IM, Eisen AZ, Wolff K, Austen KF, Goldsmith LA, Katz SI, eds), 6th edn. New York: McGraw-Hill, 2003: 836-81.

19. Kemp, DT. Otoacoustic emissions, their origin in cochlear function, and use. Br Med Bull, 2002; 63: 223-41.

20. Fabijańska A, Smurzyński J, Hatzopoulos S, et al. The relationship between distortion product otoacoustic emissions and extended high-frequency audiometry in tinnitus patients. Part 1: normally hearing patients with unilateral tinnitus. Med Sci Monitor, 2012; Dec; 18(12): 765-70.

21. Carvalho S, Mom T, Gilain L, Ayan P. Frequency specificity of distortion-product otoacoustic emissions produced by high-level tones despite inefficient cochlear electromechanical feedback. J Acoust Soc Am, 2004; 116(3): 1639-48.

22. Hamzavi I, Jain H, McLean D, Shapiro J, Zeng H, Lui H. Parametric modeling of narrowband UV-B phototherapy for vitiligo, using a novel quantitative tool: The Vitiligo Area Scoring Index. Arch Dermatol, 2004; 140: 677-83.

23. Feily A. Vitiligo Extent Tensity Index (VETI) score: a new definition, assessment and treatment evaluation criteria in vitiligo. Dermatol Pract Concept, 2014; 4(4): 18.

24. Dicle O. Assessment methods in vitiligo. J Pigmentary Disorders; 2015; 2(1): 1-2.

25. Bhor U, Pande S. Scoring systems in dermatology. Indian J Dermatol Venereol Leprol, 2006; 72: 315-21.

26. Clark J. Uses and abuses of hearing loss classification. ASHA, 1981; 23(7): 493-500.
27. Kemp, D. Otoacoustic emissions, travelling waves and cochlear mechanisms. Hear Res, 1986; 22: 95-104.

28. Dawoud EAE, Ismail EI, Eltoukhy SA, El-Sharabasy AE. Assessment of auditory and vestibular functions in vitiligo patients. J Otol, 2017; 12(3):143-9.

29. Sahrifian MR, Maleki M, Honarvar H. The correlation between vitiligo and hearing loss. Iran J Otorhinolaryngol, 2006; 17: 3-8.

30. Karsai L, Bergman M, Choo Y. Hearing in ethnically different longshore men. Arch Otolaryngol, 1972; 96: 499.

31. Gill SS, Salt AN. Quantitative differences in endolymphatic calcium and endocochlear potential between pigmented and albino guinea pigs. Hear Res, 1997;113(1): 191-7.

32. Gopal KV, Rama Rao GR, Kumar YH, et al. Vitiligo: a part of a systemic autoimmune process. Indian J Dermatol Venereol Leprol, 2007; 73: 162-5.

33. Al-Mutairi N, Al-Sebeih KH. Late onset vitiligo and audiological abnormalities: is there any association? Indian J Dermatol Venereol Leprol, 2011; 77: 571-6.

34. El Gohary ME, Behairy RA, Awida AM. Effect of vitiligo on the cochlea. Egypt J Otolaryngol, 2019; 35: 6-11.

35. Hong CK, Lee MH, Jeong KH, Cha CI, Yeo SG. Clinical analysis of hearing levels in vitiligo patients. Eur J Dermatol, 2009; 19: 50-6.

36. LaFerriere KA, Kaufman-Arenberg I, Hawkin JE, Johnsson LG. Melanocytes of the vestibular labyrinth and their relationship to microvasculature. Ann Otol Laryngol, 1974; 83: 685-94.

37. Escalante-Ugalde C, Poblano A, Montes de Oca E, Lagunes R, Saul A. No evidence of hearing loss in patients with vitiligo. Arch Dermatol, 1991; 127: 1240 .

38. Shalaby MES, El-Zarea GA, Nassar AL. Auditory function in vitiligo patients. Egypt Dermatol Online J, 2006; 2(1): 7.

39. Angrisani RM, Azevedo MF, Pereira LD, Lopes C, Garcia MV. A study on otoacoustic emissions and suppression effects in patients with vitiligo. Braz J Otorhinolaryngol, 2009; 75(1): 111-5.

40. de Jong MA, Adelman C, Gross M. Hearing loss in vitiligo: current concepts and review. Eur Arch Otorhinolaryngol, 2017; 274: 2367-72.

41. Arya R, Munjal SK, Panda NK, Prasad D. Audiological and electrophysiological changes in patients with vitiligo. Indian J Otolaryngol Head Neck Surg, 2016; 68(4): 417-23.

42. Schrott A, Spoendlin H. Pigment anomaly associated inner ear deafness. Acta Otolaryngol (Stockh), 1987; 103: 451-7.

43. Bassiouny A, Farid S, El Khousht M. Hearing abnormalities in vitiligo. Egypt J Otolaryngol, 1998; 15.1; 51-60. 
